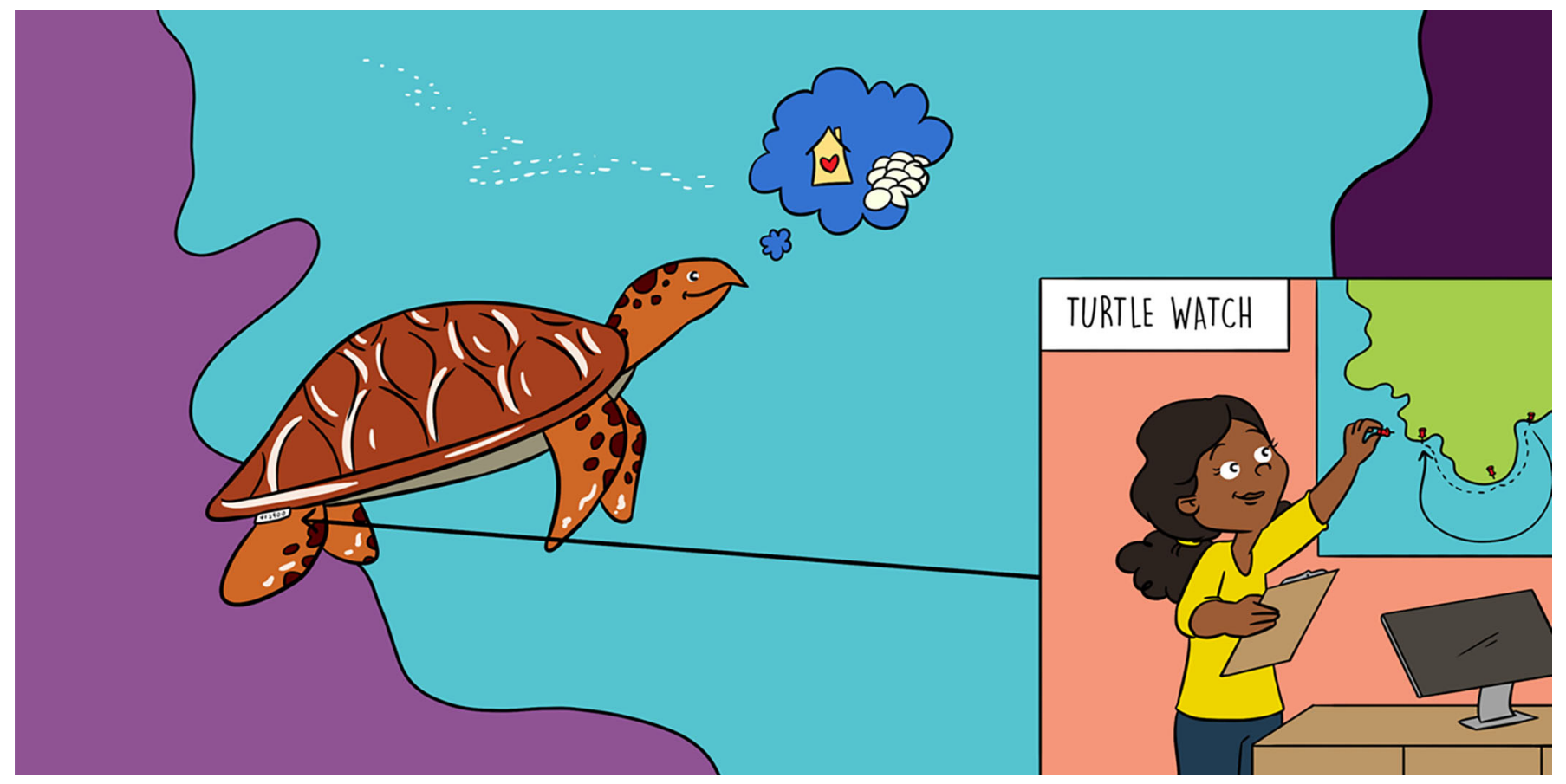

\title{
FOLLOWING THE JOURNEY OF SEA TURTLES ON THEIR QUEST FOR FOOD
}

\section{Aoife Taylor ${ }^{1 \dagger}$, Emilie Gerard ${ }^{2 *}$, Hannah Haarmann ${ }^{3}$, Mathilde Giry $^{3}$ and Maike Heidemeyer ${ }^{3}$}

${ }^{1}$ Department of Chemistry, Manchester Institute of Biotechnology, University of Manchester, Manchester, United Kingdom

${ }^{2}$ Department of Chemical Engineering and Analytical Sciences, Manchester Institute of Biotechnology, University of Manchester, Manchester, United Kingdom

${ }^{3}$ NGO Equipo Tora Carey, El Jobo, Costa Rica

\section{YOUNG REVIEWERS:}
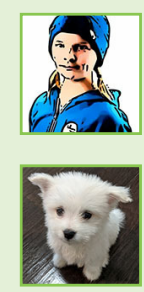

CAILLIN

AGE: 13

LILU

AGE: 11

MAIA

AGE: 10
Why is it important to know where turtles look for food? Sadly, many sea turtle species are classified as endangered. Scientists are working very hard to understand where the turtles eat and live. At different stages in a turtle's life, it requires different types of food that can come from ocean currents, protected bays, or open coastal areas. Knowing which areas the turtles prefer at which stages of their lives will help us locate them and lead to a better way of protecting all turtles, young and old. We have explored new feeding grounds along the North Pacific coast of Costa Rica. This work will help the conservation of these precious animals.

\section{WHAT IS THE LIFE CYCLE OF A TURTLE?}

A hawksbill turtle hatches from her nest on a moonlit beach, to the soft sound of waves calling. In a neighbouring nest, a male baby green 
Figure 1

The life cycle of a sea turtle, from hatching to ocean life. Different zones, or areas of the ocean, are often used during the various life stages. Females return to the same beach they were born on to lay their eggs.

\section{LOST YEARS}

No one knows exactly what baby turtles do and where they go in the first few years of their lives as they follow the marine currents. This is why scientists refer to that period as the "lost years."

\section{JUVENILE}

A turtle that has not reached adulthood. This can take up to 45 years for some species.

\section{FORAGING}

Looking for food.

\section{FEEDING GROUND}

Area where the turtles eat. Also called foraging ground

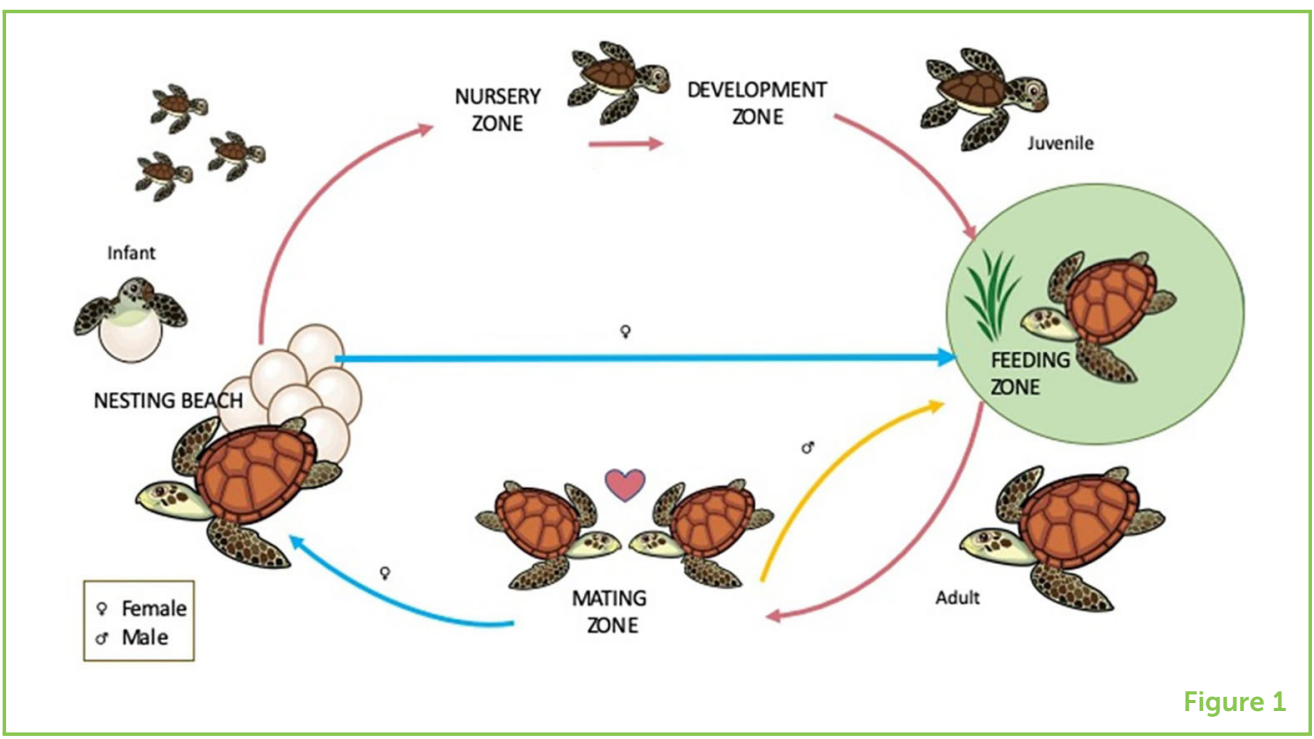

turtle is also born. As they scurry to the ocean, a raccoon and a dog are watching from the bushes. The turtles must be quick to avoid these predators! Luckily, they know where they are going; the moon's reflection on the ocean is pointing them in the right direction. Once they have crossed the crashing waves and escaped the hungry fish, they have made it to the strong marine current, where they drift for many years using branches as a natural net to catch the food they need. No one really knows where the baby turtles go or what they do during these "lost years."

After those "lost years," the turtles become teenagers (juveniles) and are so hungry that they need to find a foraging ground. This is a safe and protected place where food is plentiful and diverse; hawksbills sure do like to eat sponges and small organisms that are hiding in the coral. Green turtles will preferably look for seagrass and seaweed [1]. When the turtles become adults and want to start families, they might have to move to a larger and richer foraging ground if the one they live in becomes insufficient. As they get older and stronger, turtles can face the challenges of an unprotected bay.

Both species of turtles will look for a reproductive site where they can meet their partners. At this point the female has started her reproductive migration and set off to the beach where she hatched, to lay her own eggs (Figure 1). The male, however, will go straight back to the foraging grounds and the female will join him later. Now that we know the turtles will spend a lot of time at the feeding grounds, we will use the work of scientists to help us understand more about the lifecycle of turtles and how to protect them!

\section{HOW DOES A TURTLE CHOOSE ITS FEEDING GROUND?}

Most of the study sites are rocky, have coral, and are affected by the tide and waves. In some parts, there are also mangrove swamps and 
Figure 2

Feeding ground preferences of juvenile/adult hawksbill and green turtles in Guanacaste, Costa Rica. Juveniles are found more in areas like the protected bay of Matapalito. Adults are found in more open areas like in the bay of Cabo Blanco, alongside some juveniles still.

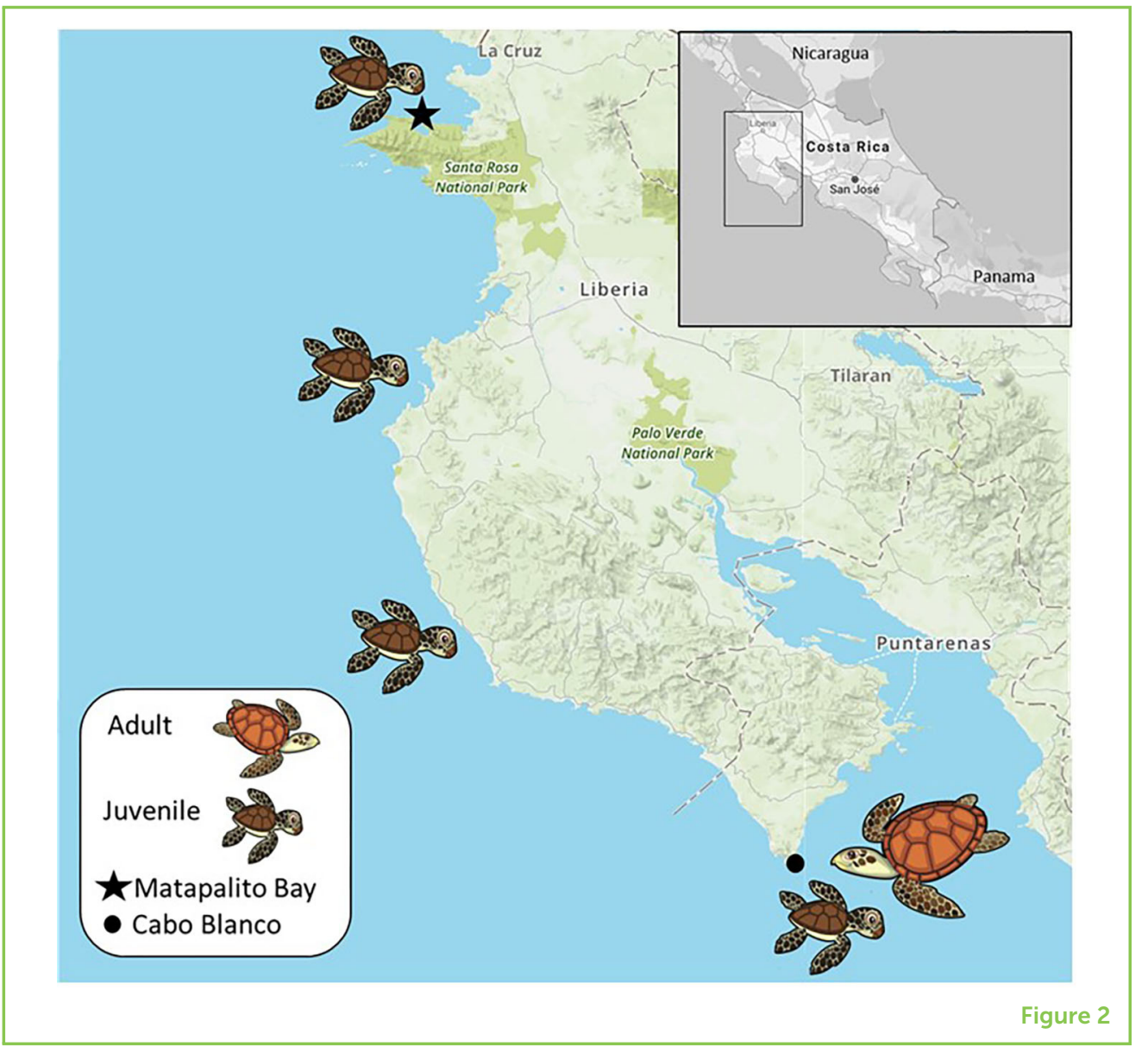

long blades of seagrass. Depending on the kind of site, we spot more turtles either in the dry season or the rainy season. This is probably due to the type of food in the sea or the arrival of food from the land, thanks to the rain. The Matapalito Bay (Bahia Matapalito) is a good example of a feeding ground where researchers are studying the turtle populations all year round (Figure 2). The bay has a sandy bottom and a coral reef, so it provides diverse feeding options. The turtles rest underneath coral formations along the edge of the reef, by the sandy stretch. Research shows that the hawksbill turtles seen at this site are mostly juvenile. This suggests that the area might be an important developmental ground for young turtles. As well as the abundance of food, the turtles probably like this bay for the many places to hide in the reef and rocks, which provide protection from larger predators. A bay, such as Matapalito also provides shelter from the rough, open sea where waves and currents can be very strong.

In Matapalito, we recaptured a small juvenile green turtle with the same characteristics as turtles in the Western Pacific. This suggests that the site is really important for juveniles, no matter where in the world they come from. This could be because there is a lot of food available and good protection provided by the bay. On other, less protected sites, for example Cabo Blanco (Figure 2), which are probably richer in food sources, we see more adults than juveniles. 
Figure 3

(A) A comparison of the physical appearance of hawksbill and green turtles. The physical differences allow us to tell the two species apart. (B) Tagging zone on the turtle's back flipper. Carapace is the technical term for the shell. Scutes are external bony plates on a turtle's shell.
A

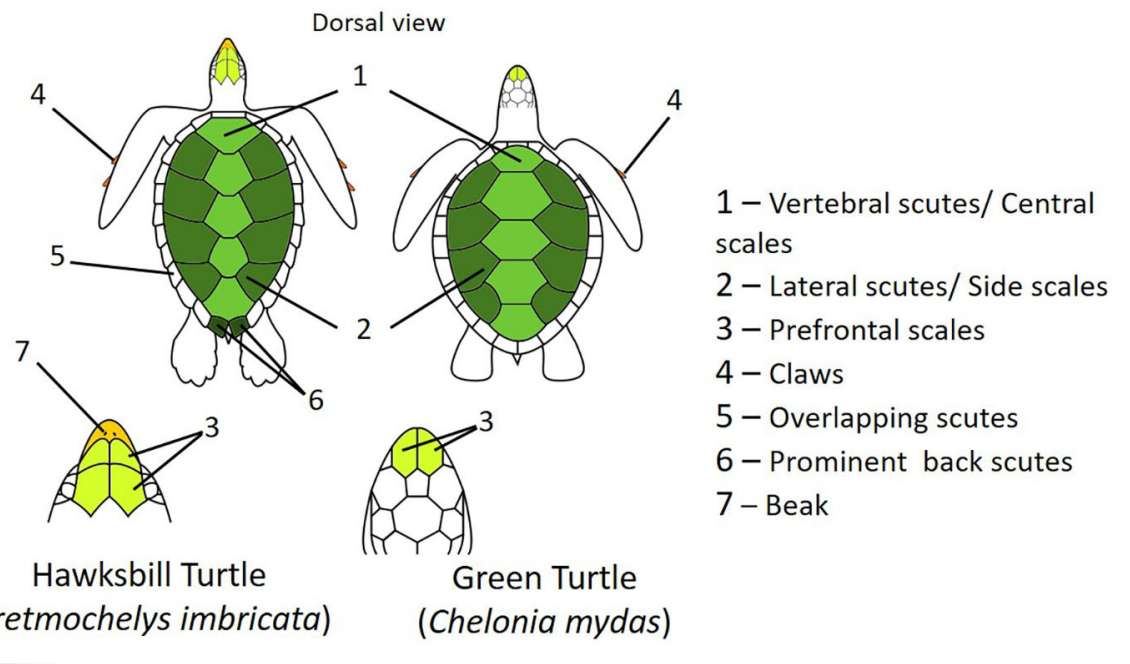

B
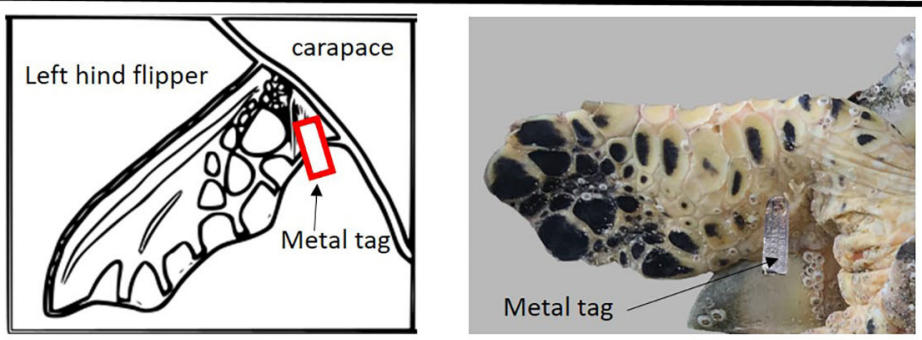

Figure 3

\section{HOW DO WE IDENTIFY TURTLES?}

We can identify a turtle's species by looking at its physical characteristics. For example, the hawksbill turtle has a pointy beak similar to a parrot and black skin with a yellow pattern on its face. The shell is sharp on the side. The green turtle, on the other hand, has green-grey skin, with a different symmetrical pattern on its face, a round head, and an oval shell (Figure 3). We identify male turtles by their long pointy tails that only grow when they have reached adulthood. This can take up to 30 years for some species!

To carry out research on turtles, we catch them by casting out a special turtle net from the boat. The net is 80 meters long and 6 meters deep, with holes 45 centimetres wide, to stop the nets from catching small fish. The turtles are brought onto the boat where they are measured, weighed, and tagged. Scientists capture and tag turtles to follow their migrations. The tag is a unique, numbered, flat piece of metal that is clipped to the turtle like an earring (Figure 3). The turtle will carry this identification number for the rest of its life. Nowadays, some scientists tag turtles on the back flipper, which has been found to be the best place [2]. When the tag is on the front flipper, the turtle is more at risk of getting caught in a fisherman's net when trying to catch an easy dinner! Once tagged, scientists around the world will be able to note where the turtle was previously captured, and therefore where it has 
been. Tagging turtles provides a lot of information on their behavior. For example, scientists have followed a green turtle that travelled all the way from Mexico to Costa Rica and back. Tagging also allows us to follow turtles that stay in the same feeding grounds for years. This is how scientists have found that some turtles are loyal to their foraging grounds-through tagging and recapture!

\section{WHAT ARE THE THREATS TO THE TURTLES?}

Most turtle species are endangered and need our immediate help to survive. There are several reasons why most sea turtles are endangered, and many of them are because of humans. For example, building hotels and houses by the beach disrupts the life cycle of turtles. Turtles like their peace and quiet; mothers will not lay eggs on busy beaches. Unnatural light is also a problem, especially for baby turtles who will confuse it with the moonlight and end up going away from the sea instead of into it.

Two highly significant reasons for the decline of all sea turtle populations are egg poaching and hunting. For example, hawksbills, which are considered critically endangered because their populations are dropping so quickly, are frequently hunted because they are the only turtles with scales on their shells, and those scales are used to make jewellery. Since they live near the coast, hawksbills are also the first species to be hunted for meat.

Additional threats to the turtles are fishing lines, hooks, and nets, which can cause turtles to get tangled or hurt, and the large quantity of plastic in the ocean, such as water bottles, shopping bags, and straws, which turtles may eat by accident, causing them to choke or have serious stomach problems [3]. These problems affect green turtles for example and that is why they are classified as endangered.

Last, global warming affects the entire life cycle of the turtle. Scientists in Brazil have shown that warmer temperatures and more sun led to fewer baby hawksbill turtles being born [4]. Increasing ocean water temperatures could also affect the sources of food the turtles might need.

\section{HOW CAN WE HELP?}

In conclusion, this article described the life cycle of two species of turtles found on the Pacific coast of Costa Rica: the green turtle and the hawksbill turtle. Furthermore, the threats faced by turtles and the importance of helping turtles by gathering data on their locations and eating habits has been explained. Scientists are working hard to understand every stage in the sea turtle's life cycle by collecting and sharing data. This is the only way to connect research with 
conservation. Some conservation strategies are already in place, for example, people around the world are taking action by patrolling the beaches to protect the eggs from poachers and predators. You can also do something to help. Everyone can! Telling your friends and family what you know about turtles and the struggles they face will help raise awareness and can promote habitat preservation. Not using objects like balloons, bottles, bags, or straws can also really help reduce the growing amounts of plastic in the ocean and save the turtles!

\section{ACKNOWLEDGMENTS}

We would like to acknowledge the contributions of $\mathrm{HH}$ and $\mathrm{MG}$ for the knowledge and effort put into this article. Furthermore, we would like to acknowledge the NGO Equipo Tora Carey. Lastly, AT and EG would like to acknowledge the BBSRC for their studentships and providing the opportunity of going on placement (under Grant No. BB/M011208/1).

\section{ORIGINAL SOURCE ARTICLE}

Heidemeyer, M., Arauz-Vargas, R., and Lopéz-Agüero, E. 2015. New foraging grounds for hawksbill (Eretmochelys imbricata) and green turtles (Chelonia mydas) along the northern Pacific coast of Costa Rica, Central America. Rev. Biol. Trop. 62:109-18. doi: 10.15517/rbt. v62i4.20037

\section{REFERENCES}

1. Van Houtan, K. S., Francke, D. L., Alessi, S., Jones, T. T., Martin, S. L., Kurpita, L. et al. 2016. The developmental biogeography of hawksbill sea turtles in the north Pacific. Ecol. Evol. 6:2378-89. doi: 10.1002/ece3.2034

2. Heidemeyer, M., Delgado-Trejo, C., Hart, C. E., Clyde-Brockway, C., Fonseca, L. G., Mora, R., et al. 2018. Long-term in-water recaptures of adult black turtles (Chelonia mydas) provide implications for flipper tagging methods in the eastern Pacific. Herpetol. Rev. 49:653-8. Available online at: https://www.researchgate. net/publication/329990945_Long-term_In-water_Recaptures_of_Adult_Black_ Turtles_Chelonia_mydas_Provide_Implications_for_Flipper_Tagging_Methods_ in_the_Eastern_Pacific

3. Wilcox, C., Puckridge, M., Schuyler, Q. A., Townsend, K., and Hardesty, B. D. 2018. A quantitative analysis linking sea turtle mortality and plastic debris ingestion. Sci. Rep. 8:12536. doi: 10.1038/s41598-018-30038-z

4. Montero, N., dei Marcovaldi, M. A. G., Lopez-Mendilaharsu, M., Santos, A. S., Santos, A. J. B., Fuentes, M. M. P. B., et al. 2018. Warmer and wetter conditions will reduce offspring production of hawksbill turtles in Brazil under climate change. PLOS ONE 13:e0204188. doi: 10.1371/journal.pone.0204188 
SUBMITTED: 11 October 2019; ACCEPTED: 06 August 2020;

PUBLISHED ONLINE: 17 September 2020.

EDITED BY: Emily King, Xiamen University, China

CITATION: Taylor A, Gerard E, Haarmann H, Giry M and Heidemeyer M (2020) Following the Journey of Sea Turtles on Their Quest for Food. Front. Young Minds 8:123. doi: 10.3389/frym.2020.00123

CONFLICT OF INTEREST: The authors declare that the research was conducted in the absence of any commercial or financial relationships that could be construed as a potential conflict of interest.

COPYRIGHT () 2020 Taylor, Gerard, Haarmann, Giry and Heidemeyer. This is an open-access article distributed under the terms of the Creative Commons Attribution License (CC BY). The use, distribution or reproduction in other forums is permitted, provided the original author(s) and the copyright owner(s) are credited and that the original publication in this journal is cited, in accordance with accepted academic practice. No use, distribution or reproduction is permitted which does not comply with these terms.

\section{YOUNG REVIEWERS}
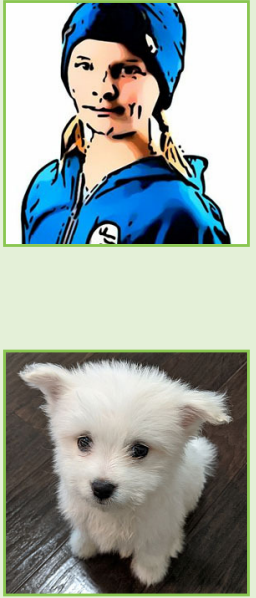

\section{CAILLIN, AGE: 13}

$\mathrm{Hi}$, my name is Caillin and I live in the Highlands of Scotland. I like to dive and snorkel and play with my pet cat, Noah. I am flameshell ambassador for the Ullapool Sea Savers, a group of kids who (like me) want to help save our beautiful seas. Flame Shells are little shellfish that live in the sea-they are really cool and have bright orange tenticles and they build reefs.

\section{LILU, AGE: 11}

I love polar bears and I am fighting against Climate Change to save them! I love my puppy and guinea pigs too.

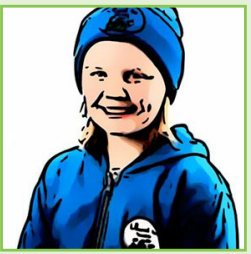

\section{MAIA, AGE: 10}

Hello my name is Maia-I am 10 years old, I live in highlands of Scotland. I love to read and play with my pet dog Polly and my cat Tatty, I also have two sisters Caillin and Kira they are very nice and kind. I am the white tailed sea eagle ambassador for the Ulapool Sea Savers, a kids marine conservation group. We work to protect our Marine Protected Area and have fun.

\section{AUTHORS}

\section{AOIFE TAYLOR}

I have a degree in chemistry and am currently doing a Ph.D. at the University of Manchester, investigating how plants make chlorophyll. My love for animals and interest in learning about conservation brought me to Costa Rica. I was amazed by 

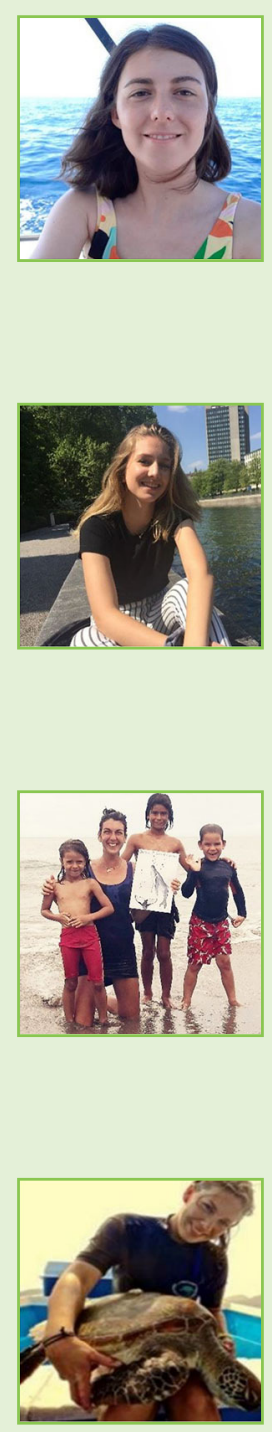

the diversity of the wildlife and particularly interested in exploring marine life. During my placement with ETC I was given the opportunity to get involved in a locally run project to protect sea turtles, it was an incredible experience!

\section{EMILIE GERARD}

I am a French/British Ph.D. student at the University of Manchester looking at quick and less energy costly way to make drugs using enzymes. I got my chemistry master's degree from the University of Sheffield in 2018. During my 3 months placement in Costa Rica at ETC, I saw many cool, diverse animals, and a lot of turtles! It was a great experience being a part of an organization that helps protect these beautiful animals. *emilie.gerardamanchetser.ac.uk

\section{HANNAH HAARMANN}

I was born in Germany, but most of my childhood was spent in Namibia which meant going on safaris and playing outside whenever I could. In 2015, my family and I moved to Switzerland where I finished school. For my gap year I volunteered for 3 months in Costa Rica with Equipo Tora Carey and 1 month in Malawi working with the Lilongwe Wildlife Centre. Soon, I will be starting my studies in wildlife conservation and see where life takes me from there.

\section{MATHILDE GIRY}

I am originally from France and have lived in Costa Rica since 2009, where I and my husband raise my son Noa amidst nature. I am the Environmental Educator for a local NGO, ETC, where I assist in marine life research. I also translate scientific data into accessible language, especially for kids from coastal communities. My values for conservation are extended into my everyday practices. As a professional kite surfer and captain, I promote nature-based sports and eco responsible behavior.

\section{MAIKE HEIDEMEYER}

I am originally from Germany and graduated from the University of Costa Rica with a Master's in biology, where I am currently working as a researcher. I have been researching sea turtles for over 10 years and am the co-founder of the NGO "Equipo Tora Carey."

${ }^{\dagger}$ These authors have contributed equally to this work 